Volume XXI, 40 - No.1, 2019, DOI: 10.35116/aa.2019.0010

\title{
THE IMPORTANCE OF AIR TRANSPORT FOR THE DEVELOPMENT OF TOURISM IN SLOVAKIA
}

\author{
Edina JENČOVÁ, Iveta VAJDOVÁ*, Stanislav SZABO jr., Peter DAŇKO, \\ Radoslav RABATIN \\ Department of Air Transport Management, Faculty of Aeronautics, Technical university of Kosice \\ Rampová 7, 04121 Košice \\ *Corresponding author. E-mail: iveta.vajdova@tuke.sk
}

\begin{abstract}
Tourism is currently an integral part of the benefits to national economies. It becomes an eye-catching sector and helps a large group of other industries to prosperity and profitability. Stated contribution deals with linking tourism and air transport, which is now continually gaining in volume. Increasing volumes of air transport is a signal of increased movements of tourists, whether under national or international lines. The article is focused on tourism in Slovakia and on its influence on Slovak airports.
\end{abstract}

Keywords: Tourism; airport; civil aviation; development

\section{INTRODUCTION}

Tourism is currently a strong economic sector that provides significant benefits to national budgets and plays an important role in the national and world economy. Air transport significantly affects tourism. It has become an important industry and helps a large group of other industries to prosperity and profitability. Increasing volumes in aviation is a sign of increasing migration of tourists either within national or international lines. The article focused on tourism in Slovakia and the influence of Slovak airports on it. The importance of Slovak airports lies mainly in outbound and inbound tourism, which consists of moving tourists from and into the country. The study aimed to assess the impact of Slovak airports on tourism.

Over a few decades, tourism has seen significant growth and has become one of the fastestgrowing economic sectors in the world. Modern tourism is dependent on the development of individual countries and includes a growing number of destinations. The sector's growth dynamics have become the driving force behind socioeconomic progress [1].

According to the UNWTO, tourism refers to activities that produce characteristic tourism products (see Table 1). Typical tourism products are those that meet one or both of the following criteria:

- Tourism expenditure on a product (whether goods or services) should represent a significant share of total travel expenditure (share of expenditure/demand);

- Tourism spending on a product should represent a significant share of the supply of the product in the economy (the share of supply condition). This criterion means that the supply of the product would cease to exist without tourism and a sufficient number of visitors [1].

Typical tourism products and tourism businesses include:

- Accommodation services for visitors/ Accommodation facilities

- Food and snacks/ Catering facilities 
- Railway transport services/ Railway passenger transport

- Road transport services/ Passenger transport by road

- Water transport services/ Water passenger transport

- Air transport services / Air passenger transport

- Rental of transport equipment/ Rental of transport equipment

- Travel agencies and other reservation services/ Travel agencies and other reservation services

- Cultural services/ Cultural enterprises

- Sports and recreation services/ Enterprises engaged in sports and recreational activities

- Typical goods for the tourism of a particular country/ Retail shops with characteristic goods for the tourism of a particular country

- Characteristic tourism services of a particular country/Other activities for characteristic tourism services of a particular country.

\section{TOURISM}

Tourism is a dynamic and competitive industry that requires the ability to constantly adapt to the changing needs and wishes of customers, such as customer satisfaction, safety, and more.

\subsection{Worldwide tourism}

According to the UNWTO, tourism has boasted virtually uninterrupted growth over time, demonstrating the sector's strength and resilience. International tourist arrivals have increased from 25 million globally in 1950 to 278 million in 1980, 674 million in 2000, and 1,235 million in 2016 [2].

Likewise, international tourism receipts earned by destinations worldwide have surged from US\$ 2 billion in 1950 to US\$ 104 billion in 1980, US\$ 495 billion in 2000, and US\$1,220 billion in 2016 [2].

According to the UNWTO, international tourist arrivals worldwide are expected to increase by $3.3 \%$ a year between 2010 and 2030 to reach 1.8 billion by 2030, according to UNWTO's long-term forecast report Tourism Towards 2030 [2].

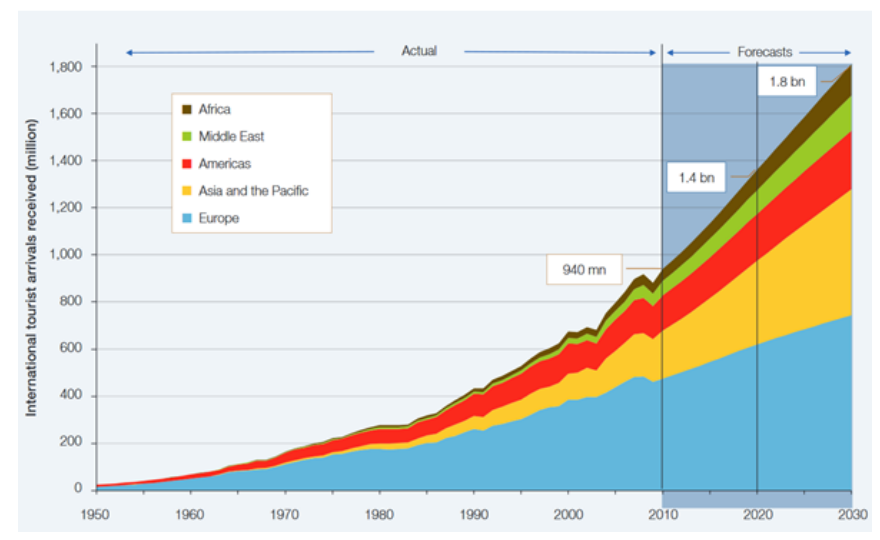

Figure 1 UNWTO Tourism Towards 2030 [2]

In 2016, slightly over half of all overnight visitors travelled to their destination by air (55\%), while the remainder travelled by surface transport $(45 \%)$ - whether by road $(39 \%)$, rail $(2 \%)$ or water $(4 \%)$ 
(See in Figure 2). The trend over time has been for air transport to grow at a somewhat faster pace than surface transport; thus, the share of air transport is gradually increasing [2].

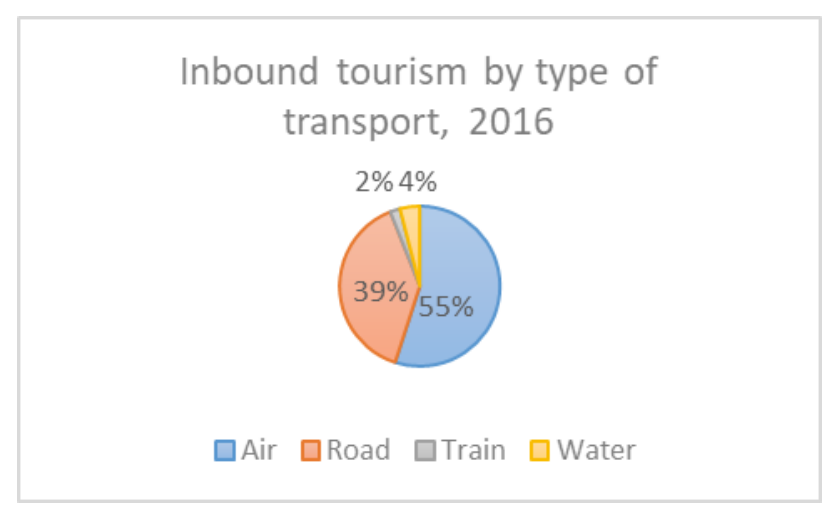

Figure 2 Inbound tourism by type of transport, 2016 [2]

\subsection{Tourism in Slovakia}

Tourism is one of the most dynamic emerging industries, and in Slovakia has already expanded so much that we consider it an economic sector. Under Slovak conditions, tourism has the potential to expand significantly, thanks to the natural and historical potential of the country, thus contributing to the state budget.

Currently, tourism is not an integrated sector in the conditions of Slovakia and its inputs and outputs from the national economy cannot be measured as in other sectors, agriculture, or industry. Figure 3 shows development of balance of payments in tourism (in mil $€$ ) in the reporting period [3].

The position of Slovakia in the heart of Europe creates a good potential for tourism development. There are many accommodation facilities and catering facilities built-in connection with tourism. Among the most popular tourist attractions in Slovakia are high mountain tourism, ski resorts, and historic towns.

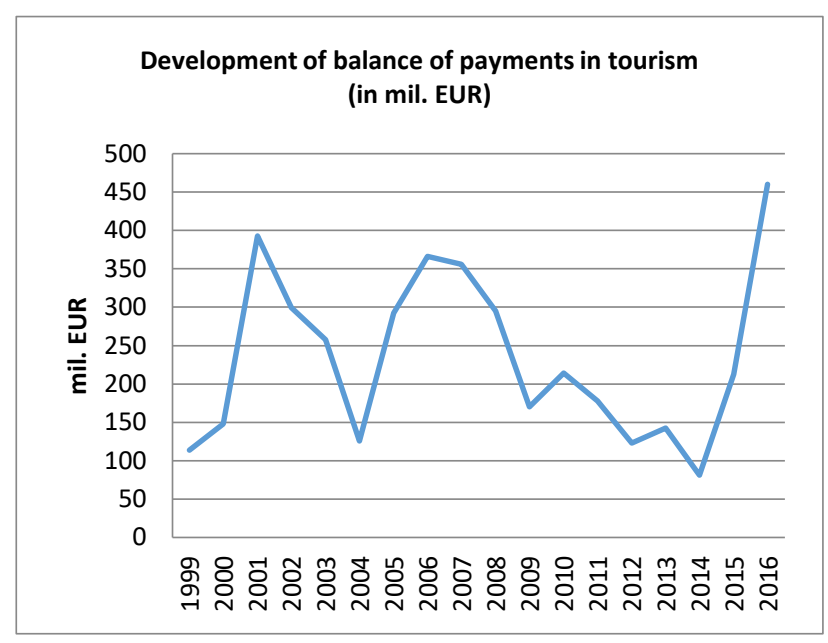

Figure 3 MDVRR SR Tourism Statistics of the Slovak Republic - Development of the Balance of Payments of the Slovak Republic for 1997 - 2016 [3]

According to the UNWTO, in Central and Eastern Europe, arrivals increased by $4 \%$ in 2016. Many destinations enjoyed strong results, including Georgia $(+19 \%)$, Slovakia $(+17 \%)$, Bulgaria $(+16 \%)$, Romania and Lithuania (both $+11 \%$ ). Hungary and Ukraine both recorded a $7 \%$ growth in arrivals, while Poland and the Czech Republic both reported an increase of 4\%) [2]. 


\section{AIR TRANSPORT FROM THE PERSPECTIVE OF TOURISM}

Air transport is an integral part of tourism. The development of air transport has shaped the tourism industry in many countries in the world. Progress in aircraft technology, improved communications and information technologies, and marketing strategies have improved quality of air transport and reduced ticket prices, thereby increasing the volume of air transport, particularly in long ways [5]. The relationship between air transport and tourism is complex and includes the accessibility of tourism, economic factors and the demand for low-cost carriers [6].

Aviation provides the world's only transport network, which makes it an integral part of global business and tourism. It also plays an important role in supporting economic growth, especially in developing countries.

Figure 4 shows the connection and interaction between air transport and tourism, in their general understanding.

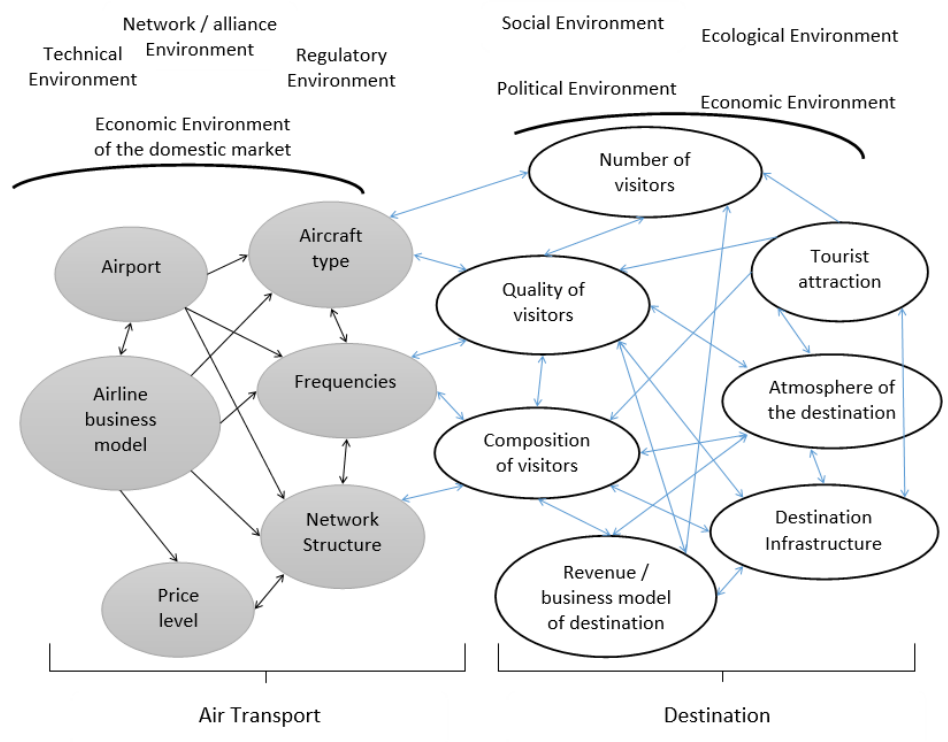

Figure 1 Connection and interaction between Air transport and Tourism [1]

\section{INFLUENCE OF AIR TRANSPORT ON TOURISM IN SLOVAKIA}

The increasing volumes of air transport in Slovakia, and thus the increasing share of this transport in tourism, points to the need to address the major air transport problems in the Slovak Republic. Since civil aviation is an essential part of the transport system covering the area of passenger and freight transport, especially in terms of cross-border accessibility of Slovakia. Increased competition in this sector requires a corresponding upgrading of the infrastructure and services provided, together with sufficient information support [7].

Among the basic tasks that the Slovak Republic has in the field of air transport include the modernization and building of civil aviation infrastructure for the economic development of the country and the region and the improvement of the quality of provided services.

Measures to modernize, construction and maintenance of airport infrastructure is based on the range of needs of airport companies, on the side of operational infrastructure, such as:

- Comprehensive modernization of airport infrastructure,

- The construction of a new freight transport infrastructure,

- Infrastructure measures in the form of maintenance work. 
The implementation of the measures is to ensure the continuous creation of conditions allowing the development of the civil aviation sector. The measures stem from the creation of active instruments to support the entry of important carriers on the market to develop mobility and promote economic and regional development and to ensure the functional, quality and operational state of the optimized civil aviation network of the Slovak Republic [7]. Table 1 shows key problems of civil aviation in perspective of tourism.

Table 1 Key problems of civil aviation in perspective of tourism [7]

\begin{tabular}{|c|c|c|c|c|c|}
\hline \multicolumn{2}{|r|}{ KEY PROBLEMS OF CIVIL AVIATION } & $\begin{array}{l}\text { PLANNING } \\
\text { AREA }\end{array}$ & \multicolumn{3}{|c|}{ INFRASTRUCTURE AREA } \\
\hline ID OP. & Measures & 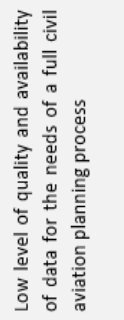 & 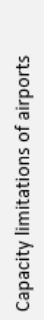 & 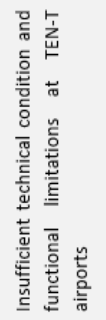 & 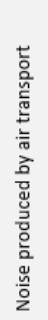 \\
\hline OPL1 & $\begin{array}{l}\text { Optimization of airport systems operated by airport } \\
\text { companies to ensure functional and efficient civil aviation } \\
\text { development planning }\end{array}$ & & $\mathrm{x}$ & $\mathrm{x}$ & \\
\hline OPL2 & $\begin{array}{l}\text { Modernization and building of civil aviation infrastructure } \\
\text { for the purpose of economic development of the country } \\
\text { and region and improvement of the quality of the services } \\
\text { provided }\end{array}$ & & $\mathrm{x}$ & $\mathrm{x}$ & \\
\hline OPS1 & Set up sustainable transport financing principles & & & & \\
\hline OPS2 & $\begin{array}{l}\text { Periodic preparation of transport infrastructure } \\
\text { maintenance plans }\end{array}$ & & & $\mathrm{x}$ & \\
\hline ops3 & $\begin{array}{l}\text { Process of preparation and implementation of } \\
\text { development projects, including related activities }\end{array}$ & $\mathrm{x}$ & & & \\
\hline OPS4 & $\begin{array}{l}\text { Addition and ongoing maintenance of the databases of } \\
\text { individual subsectors }\end{array}$ & $\mathrm{x}$ & & & \\
\hline OPS5 & $\begin{array}{l}\text { Improving functionality and managing the multimodal } \\
\text { transport model of the Slovak Republic }\end{array}$ & & & & \\
\hline OPS6 & Regular updates of strategic and development documents & & & & \\
\hline OPS7 & $\begin{array}{l}\text { Regular monitoring of noise and air quality and } \\
\text { implementation of measures reducing the negative } \\
\text { impacts of traffic on the environment }\end{array}$ & & & & $\mathrm{x}$ \\
\hline OPS8 & $\begin{array}{l}\text { Regular implementation of security audits and } \\
\text { implementation of transport safety measures }\end{array}$ & & & $\mathrm{x}$ & \\
\hline
\end{tabular}

The increase in the number of passengers carried shows the increasing impact of Slovak airports on tourism. Table 2 and Table 3 shows increase in aviation's impact on tourism in the reference period globally and according specific airport.

Table 2 Number of passengers carried in the reference period [9]

\begin{tabular}{|c|c|c|c|c|c|c|c|c|c|c|}
\hline \multicolumn{2}{|l|}{ Year } & 1995 & 2000 & 2005 & 2010 & 2011 & 2012 & 2013 & 2014 & 2015 \\
\hline \multicolumn{2}{|c|}{ Passengers (in mil.) } & 0,326 & 0,429 & 1,643 & 1,971 & 1,897 & 1,712 & 1,660 & 1,769 & 2,098 \\
\hline \multirow{3}{*}{$\begin{array}{l}\text { Commercial } \\
\text { air transport } \\
\text { (in mil.) } \\
\text { Other }\end{array}$} & International & 0,282 & 0,391 & 1,501 & 1,875 & 1,817 & 1,644 & 1,611 & 1,723 & 2,054 \\
\hline & National & 0,035 & 0,028 & 0,126 & 0,082 & 0,065 & 0,057 & 0,039 & 0,036 & 0,032 \\
\hline & & 8891 & 9543 & 15070 & 14000 & 14764 & 10072 & 9747 & 9818 & 11897 \\
\hline
\end{tabular}

Table 3 Number of passengers carried by airports in the reference period [9]

\begin{tabular}{|c|c|c|c|c|c|c|c|c|c|}
\hline Year & 1995 & 2000 & 2005 & 2010 & 2011 & 2012 & 2013 & 2014 & 2015 \\
\hline Airports together & 100,00 & 100,00 & 100,00 & 100,00 & 100,00 & 100,00 & 100,00 & 100,00 & 100,00 \\
\hline Bratislava & 65,439 & 66,048 & 80,706 & 84,476 & 83,515 & 82,697 & 82,702 & 76,613 & 74,546 \\
\hline Košice & 23,659 & 29,296 & 16,420 & 13,544 & 14,037 & 13,768 & 14,285 & 20,162 & 19,560 \\
\hline Pieštany & 1,007 & 1,324 & 0,377 & 0,072 & 0,028 & 0,029 & 0,054 & 0,111 & 0,097 \\
\hline Sliač & 1,448 & 0,357 & $1 ? 104$ & 0,000 & 0,763 & 1,610 & 1,455 & 1,337 & 1,700 \\
\hline Poprad & 8,447 & 2,975 & 1,116 & 1,404 & 1,297 & 1,796 & 1,480 & 1,764 & 4,055 \\
\hline Žlina & - & - & 0,277 & 0,503 & 0,359 & 0,100 & 0,025 & 0,014 & 0,042 \\
\hline
\end{tabular}




\subsection{Airport M.R. Stefanik and its impact on tourism}

Bratislava Airport offers tourists the services of the Bratislava tourist region as well as the surrounding regions, which do not have an air connection such as Dolnopovažský region, Záhorský region, or Nitriansky region. Each of these regions offers several attractive tourist areas [4], [9][8].

Since the airport has the largest number of airlines, and in terms of airport volumes, it transports the largest number of passengers, its contribution to tourism is considerable. Passenger volumes depend on the number of destinations offered, so the airport must expand its offer continually.

At the airport currently offers its services to scheduled airlines and charter companies providing the number of holiday destinations. From regular destinations are offered at the airport flights to Italy, Russia, Ireland, the United Kingdom, Germany, Spain, the Czech Republic, Greece, Belgium, and the United Arab Emirates, and within Slovakia. A total of 26 regular flights are available at the airport. The low-cost Ryanair provides most of the scheduled destinations.

The airport has to make every effort to ensure that the offer of destinations constantly increased and that services at the airport are acceptable to passengers. The effort was also reflected in the results when M.R.Stefánik Airport in Bratislava reached the third-highest operating result in its history in 2017 and the highest result in the last nine years. Last year, a total of 1942069 passengers were equipped by Bratislava Airport, which is $11 \%$ more than a year earlier [10].

\subsection{Kosice Airport and its impact on tourism}

Košice airport is more connected with tourism compared with Bratislava airport, especially since 2013 when it was the European Capital of Culture. Kosice is the center of the East Slovak region, and Kosice Airport offers a transport air hub in regions such as Košický, Dolnozemplínsky, Hornosplínsky, Šarišský or Spišský region [4],[9][8].

Košice Airport is the second largest in Slovakia, and with gradually offers to expand destinations and airlines is a major contributor to Slovak tourism [16].

The airport cooperates with several partners in the field of tourism such as Košice, Kosice Selfgoverning Region, regional tourism organization Košice Tourism and others. With the partners mentioned above, working to improve air access to eastern Slovakia further. Aviation availability is essential for the long-term development of the city and the region. With the opening of new lines and an increasing number of destinations, Košice Airport increases the attractiveness of the region. Further expansion of tourism in the region has followed by the opening of a new LOT line to Warsaw or the connection of a major Turkish carrier to Istanbul. Opening new lines strongly support the migration of tourists in the region, both domestic and foreign [12].

In 2017, Kosice Airport provided 496,708 passengers, an increase of $13.7 \%$, respectively by 60,012 passengers compared to the previous year. 373,406 passengers used regular flights and 121,230 charter flights [13].

The largest share was the segment of charter transport, in which the number of passengers transported grew by 35410 passengers year on year (an increase of $41.3 \%$ ). In the regular carriage segment, an increase of 24,427 passengers $(+7.0 \%)$ recorded [13].

\subsection{Poprad - Tatry Airport and its impact on tourism}

Poprad - Tatry Airport has an important position, especially in the field of Tatras tourism. Its strategic location near High Tatras can be considered positive, but the number of lines and connections at the airport is inadequate. Many tourists arriving in the High Tatras used by Košice Airport, which has a higher number of airlines [4], [9][8]. Positive at Poprad airport was the opening of the WizzAir line to London, which made the region available, creating the impetus for foreign tours to the High Tatras. It immediately reflected in the number of passengers transported. AirBaltic offers seasonally regular flights to Riga at the airport [14]. 


\subsection{Airports Žilina, Sliač and Piešt’any and their impact on tourism}

Žilina airport is located in north-western Slovakia and is part of the Beskydy region. Zilina Airport operates mostly flights for foreign business clients of individual business entities in the region. From the perspective of active tourism, the airport used considerably less, but it expects to increase the clientele especially for spa or tourism such as Rajecké Teplice, Bešeňová, Vrátna and the like. It is clear that this region has something to offer to tourists, but the air transport link to the airport of Zilina is without regular flights. The airport currently used for charter and business flights and practical flight training, which does not contribute to the increase in tourism in Slovakia [4], [9][8].

Sliac Airport is one of the small Slovak airports, whose performance is minimal. The main function of the airport is the promotion of tourism development in the region, but the airport does not provide any regular flights to foreign tourists to the region. The airport provides only "Outbound" tourism, by charter companies, especially during summer months, to the seaside resorts of Bulgaria, Turkey, Greece, and Egypt. Airport performance is more or less focused on air freight, and therefore does not contribute to the increase in tourism in the area [15].

The airport in Piestany also does not provide a regular line and a minimum number of charter lines. Its performance does not contribute to the development of tourism in Slovakia in any way.

To expand and modernize Slovak airports and thereby increase their impact on tourism in Slovakia, a road transport development plan, which deals with the introduction of this chapter, was developed[15].

\section{CONCLUSION}

Global tourism in the world cannot exist in isolation from transport, and it can, therefore, said that there is a strong positive correlation between tourism and transport. Improving or modernizing transport or, on the other hand, worsening transport has a direct impact on tourism [17]. The Slovak Republic is in terms of tourism, at the beginning because the volumes of tourists are not far from what they might be. The disadvantage of the impact of aviation on tourism in Slovakia is that it is a relatively small country and national tourism by air transport not particularly used. In this direction, land transport modes preferred. From international tourism, the use of air transport is more significant. Among the six international airports located in Slovakia, only Bratislava and Kosice airports contribute significantly to the increase in tourism. Other airports have little or no benefit for increasing tourism in Slovakia. From the future development of each airport about tourism, each of these airports has the possibility of increasing demand for individual flights, as well as the possibilities of opening new lines.

An increase in air traffic awareness in Slovakia is also reflected in the strategic development plan for transport by 2030, where the emphasis also placed on the development of Slovak airports as important contributors to the development of tourism.

\section{References}

[1] Biegera, T. - Wittmerb, A. 2006. Air transport and tourism-Perspectives and challenges for destinations, airlines and governments. In: Journal of Air Transport Management. Volume 12, Issue 1, January 2006, Pages 40-46. DOI: https://doi.org/10.1016/j.jairtraman.2005.09.007

[2] UNWTO 2017. Tourism Highlights. 2017 Edition. ISBN: 978-92-844-1902- Available at: https://www.e-unwto.org/doi/pdf/10.18111/9789284419029

[3] MDVRR SR. Tourism Statistics of the Slovak Republic - Development of the Balance of Payments of the Slovak Republic for 1997 - 2016. Available at: http://www.telecom.gov.sk/index/index.php?ids=96673

[4] MDVRR SR. Tourism in Slovakia. Available at: http://www.telecom.gov.sk/index/index.php?ids=104564 
[5] Ferenc, J. - Ferencová, J. - Koščák, P.: Evaluation of competitiveness of airports. 2011. In: Acta Avionica. Vol. 13, i. 21 (2011), pp. 68-76. - ISSN 1335-9479

[6] The Impact Of Air Transport On Tourism. Tourism Essay. 2015. Available at: http://www.ukessays.com/essays/tourism/the-impact-of-air-transport-on-tourism-tourismessay.php

[7] MDVRR SR. Strategic Transport Development Plan of the Slovak Republic until 2030 - Phase II. Available at: http://www.telecom.gov.sk/index/index.php?ids=214001

[8] Vokáč, R. - Szabo, S.: Passengers' satisfaction as a key factor for airport business and handling activities. 2016. In: New Trends in Civil Aviation 2016. - Žilina: Edis, 2016 pp. 112-114. - ISBN 978-80-554-1252-8

[9] MDVRR SR. Airports Performance. Available at: http://www.telecom.gov.sk/files/statistika_vud/vykony_letisk.htm

[10] Bratislava Airport. Annual Reports. Available at: http://www.bts.aero/en/aboutus/press/annualreport/

[11] Košice Airport. 2011 Available at: http://mojelietadla.717.cz/menu/letiska/letisko-kosice

[12] Košice International Airport. News. Available at: http://www.airportkosice.sk/aktuality/

[13] Košice International Airport. 2018. The most successful year in terms of connectivity in Eastern Slovakia. Available at: https://www.airportkosice.sk/sk/precestujucich/aktuality/najuspesnejsi-rok-z-pohladu-konektivity-vychodneho-slovenska

[14] Poprad - Tatry Airport. Statistics. Number of passengers carried in 2010 - 2015. 2016 Available at: http://www.airport-poprad.sk/sk/podstranky/letisko/statistiky.php

[15] Žilina Airport. Statistics. 2016 Available at: http://www.letisko.sk/statistiky/

[16] Hut'anská, M. - Koščák, P.: Eastern Slovakia as a Hub of Logistics and Transportation. 2013. In: Acta Avionica. Vol. 15, i. 27 (2013), pp. 1-5. - ISSN 1335-9479

[17] Koščák, P. - Udičová, D. - Kolesár, J.: Návrh budúceho rozvoja vybraného letiska. 2018. In: Zborník vedeckých prispevkov Leteckej fakulty Technickej univerzity v Košiciach Košice (Slovensko): Technická univerzita v Košiciach pp. 29-33 ISBN 978-80-553-3214-7.

[18] Galanda, J. - Bodnár, T.: Cloud computing v akademickom prostredí Leteckej fakulty. 2018. In: Bezpečnost' a doprava 2018: Teória a prax v bezpečnosti a krízovom riadení v doprave. Brno (CZ): Akademické nakladatelství CERM. pp. 79-91. ISBN 978-80-7623-002-6.

[19] Szabó, P. - Galanda, J.: Výskumná činnost' a publikácie zásadného významu (v letectve), 2013. In: Aeronautika 2013. Košice: TU, 2013 pp. 277-282. ISBN 978-80-553-1416-7.

[20] Szabo, S. - Šulej, R. - Galanda, J.: Departure control systems for regional and low-cost carriers, 2018. In: New trends in civil aviation. London: CRC Press, 2018. pp. 237-244. ISBN 978-0-8153-7602-6.

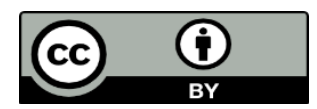

The article is licensed under a Creative Commons Attribution 4.0 International License 